\title{
The Impact of COVID-19 on the Strategic Belt and Road Initiative in the Light of Cultural Convergences and Divergences between Egypt and China: A Systematic Review
}

\author{
Safaa Shaaban'1, Yasmine Abdel Moneim² \\ ${ }^{1}$ Business Department, Faculty of Business Administration, Economics and Political Science, The British University in Egypt \\ (BUE), Cairo, Egypt \\ ${ }^{2}$ Faculty of Law, The British University in Egypt (BUE), Cairo, Egypt \\ Email: Safaa.shaban@bue.edu.eg, yasmine.moneim@bue.edu.eg
}

How to cite this paper: Shaaban, S., \& Moneim, Y. A. (2020). The Impact of COVID-19 on the Strategic Belt and Road Initiative in the Light of Cultural Convergences and Divergences between Egypt and China: A Systematic Review. Open Journal of Social Sciences, 8, 84-105.

https://doi.org/10.4236/jss.2020.89006

Received: July 27, 2020

Accepted: September 4, 2020

Published: September 7, 2020

Copyright $\odot 2020$ by author(s) and Scientific Research Publishing Inc.

This work is licensed under the Creative Commons Attribution International License (CC BY 4.0).

http://creativecommons.org/licenses/by/4.0/

(c) (i) Open Access

\begin{abstract}
China unveiled a historical initiative named the "Belt and Road Initiative" (BRI) launched in 2013, by the Chinese President "Xi Jinping" which will extend the Chinese influence to large regions of the world through a network of roads, ports and airports' infrastructure projects. It represents China's desire to revive the old Silk Road in order to reshape the world's powers by the creation of a new balance in the International System. The MENA region is ranked as one of the highest areas in the era for Chinese investment. Egypt is considered as one of the top countries which will take part in this investment in the MENA region and Africa. The purpose of this study is to systematically review the Convergences and Divergences between Egypt and China from a cultural perspective using Hofstede and GLOBE Models and their impact on the strategic cooperation between both countries towards the Belt and Road Initiative and the impact of COVID-19 on this initiative. The methodology of this study is to review researches and studies conducted and published in the period from 2010 to 2019. More than 13 studies were identified for analysis and study. The study yields to three results in both Hofstede and GLOBE Models: 1) in LTO China scored higher than Egypt; 2) both China and Egypt were scored closer to collectivism; and 3) In PDI, China has scored higher than Egypt but not that much as the difference is only 10. However, in the GLOBE Model, the differences in PDI and IDV dimensions are not as great as in Hofstede Model.
\end{abstract}

\section{Keywords}

Culture, Hofstede \& GLOBE Models, Belt and Road Initiative (BRI), COVID-19 


\section{Introduction}

China showed a high interest and concern in 2013, regarding the regeneration of "The Belt and Road Initiative" (BRI) that will create an economic belt taking the place of the old Silk Road. This project is considered one of the best, unique and ambitious mega projects in the economic word with reference to its geographical and cultural aspects. The main objectives of the BRI are to develop a network of infrastructure and trade which will link Asia to Africa and Europe similar to what happened in the old Silk Road. It also aims to increase the trade between the contributing states, improve, develop, and upgrade the infrastructure in these states. Furthermore, the Initiative agrees upon the "partnership" principle in the distribution of the development's profits among the participating states. The Belt and Road Initiative has taken place by China to include as much as possible politically, economically and culturally diverse states in the MENA region. The benefits of this Initiative will be remarkable as China "boasts a rapidly developing economy with unprecedented levels of industrialization" (Managa \& Simelane, 2018: p. 75). As a result of these initiatives, an important number of organizations in MENA region, mainly in Egypt, participate in the Initiative to implement many projects of cooperation with many Chinese organizations on the level of public and private sectors. Egypt is ranked in the Refinitiv BRI Database as the country "with the second-highest number of BRI-linked projects by volume after Russia, with 109 under construction or in the pipeline. It also has the seventh-highest cumulative value of BRI-linked projects (almost $\$ 100 \mathrm{bn}$ )" (Refinitiv BRI database).

Miller (2004) defines the concept of organizational culture as "organizations, cognitive attitudes, beliefs and behaviors and its values" (p. 19). Similarly, Morgan (1997) describes corporate culture as "an active living phenomenon through which people jointly create and recreate the worlds in which they live" (p. 135). Schachter (2005) remarks that culture will control and establish an organization's survival over the long term. Hofstede (2011) has defined culture as "the collective programming of the mind that distinguishes the members of one group or category of people from others" (p. 3). He described it as a share collective phenomenon, but it can be connected to various collectives. In each collective, the individual is varying. The most frequent term of culture is used for a group of people (in anthropology), for nations (in political science, sociology and management), and for organizations (in sociology and management) (Shi and Wang, 2011). The concept of "culture" refers to the societal, national and gender cultures where children learn from their early years, youth onwards are much deeper rooted in the human mind than job/organization cultures acquired at school, or than organizational cultures acquired on the job (Hofstede, 2001). All studies reveal the common finding that there is a strong correlation between leadership and culture. Schein (1992) argues that the organizational culture and leadership are intertwined. Another argument raised by Bass and Avolio (1993) mirror the argument of Schein (1992) by proposing that the relationship be- 
tween leadership and culture represents a continuing interaction that helps the leader outlines and forms the culture and is in turn shaped by the subsequent culture. A study showed that the different style of leaders has a big impact on culture, also leaders are considered in some cases the founder of culture (Bass, 1985). The main influence of leader's different style is culture. Holt, Bjorklund, and Green (2009) conducted a research that explored the elationship between leadership perceptions and cultural.

China is considered one of the three top adopting and leading the economic market since 1979. Although China has adopted western management instruments and the fundamental ideologies of the market, it still keeps its traditional management concept and way (Confucian-based) principles. At the same time, while China adopts western ideas in management, western business has also become aware of the Chinese principles and ways in management. This paper discusses how the cross-culture can show similarities and differences; nevertheless, possible high level of cooperation and understanding of each other can exist and reinforce this relationship (King and Zhang, 2014). It is worldwide known that Egypt is considered as one of the most important national cultures in the world and a central hub in the Middle East and in Africa. It would seem that the Egyptian organizational culture was strongly influenced by the national culture (Nafie and Jones, 2012).

Although there are many studies that took the initiative to study the Chinese Culture and its adaptation to other cultures such as western, American, Russian and Germen Culture, and other researches considered the Egyptian Culture with the American Culture, there is a lack of comparative studies between the Chinese Culture and the Egyptian Culture. This study aims to bridge the gap in the literature related to comparing the Egyptian Corporate Culture with the Chinese Culture, and to recommend further related researches in the future. Once this data has been determined for further researches, a relationship and more cooperation can be drawn based on the business and management perspective.

There is a big need to investigate the concept of culture more about their impact on the entrepreneurial Procedure. The culture interaction should consider its factors further in-depth analysis, and also to take into consideration the comparison between a different period of time especially in Arab countries which will give more explanation about the concept of trust as a value in these countries (FakhrElDin et al., 2013).

This paper briefly describes the Chinese and the Egyptian Culture using Hofstede six dimensions Model of national cultures: Power Distance, Uncertainty Avoidance, Individualism/Collectivism, Masculinity/Femininity, Long/Short Term Orientation, and Indulgence/Restraint. Furthermore, this study will use GLOBE Model that includes nine dimensions: Uncertainty Avoidance, Power Distance, Institutional Collectivism, In-Group Collectivism, Gender Egalitarianism, Assertiveness, Future Orientation, Performance Orientation, and Humane Orientation.

The main interest of this study is to analyze the literature on the similarities 
and variations of culture between Egypt and China by assessing the intention of the researcher. Many authors identified the importance of researchers' interests and rationale in their studies. Alvesson (2002) pointed out how studies can serve similar research interests, while authors like Girginov (2010) suggested that researchers should place themselves related to the rationale for their studies. Motives for study research may thus search for knowledge related to one of these three practical theories and to understand the technicality of the study to predict, to control, and to emancipatory by exposing and removing different parts (Girginov, 2010).

The main purpose of this study is to systematically review the culture evaluation in China and Egypt from the similarities and differences perspective in order to incorporate the existing literature and studies. Authors such as Weed expressed their concern towards the knowledge, maybe made different studies that are "thrown on the pile of research without any consideration as to how bodies of knowledge could be created" (Weed, 2005: p. 79). Explicitly, through systematical literature review, any study should answer two questions: First, what are the designs and logical trends used by researchers to be able to use epistemology, methodology, interests, perspectives, and methods in evaluating the cultural dimensions in the two countries? Second, how can this pattern provide the reader with a fundamental ground to evaluate the cultural dimensions? (Culver, Gilbert, and Sparkes, 2012). The pattern includes the direction across all targeted studies for criteria, such as tools used for evaluation, interest and methodology. The same apply for the coherent occurrence of several criteria in one study.

\section{Study Objectives}

The main objectives of this study are to clarify the Egyptian and Chinese positions on each of Hofstede's six dimensions and GLOBE Models. To analyze the Egyptian culture and the Chinese culture pointing out the similarities and differences. To examine if the Egyptian Culture has similar values, believes and norms as the Chinese Culture. To ascertain whether the Egyptian Culture can be compatible and in harmony with the Chinese Culture; to clarify the impact of COVID-19 on the Chinese Belt and Road Initiative.

\section{Research Questions}

This study will work to answer these questions are: Does the Egyptian Culture share the same Chinese Culture values? Does the Egyptian Culture differ from the Chinese Culture? Do the convergences and divergences between China and Egypt influence their strategic cooperation? Does COVID-19 affect the Chinese economic activity, especially the Belt and Road Initiative?

\section{Methodology}

The systematic review widely employs methods and well-known synthesis approach which has been used across cultural studies, human and organizational 
behaviors. Systemic review defined by Klassen, Jahad, \& Moher (1998) as "A review in which there is a comprehensive search for relevant studies in specific topic, and those identified are then appraised and synthesized according to a pre-determined method" (p. 79). Therefore, the approach of research required first aim for wide-ranging covered treatment of a particular topic-natural of culture in Egypt and China and similarities and Variations in this instance, this can be conducted through searching of applicable and suitable electronic databases. This review includes but not limited to studies that compare the Egyptian Culture with other nation's culture same apply to Chinese Culture. The review has included journals across a range of disciplines like management, sports, human resources, and medicine "Table 1" below.

Second, systematic review must deliver a clear framework, such as the only studies related to the topic are targeted in the study. This research study only included peer-reviewed articles and research reports on culture dimensions' analysis in both countries. The criteria for the review were clearly explained in "Table 1 " as a result of reviewing 13 studies employing the systematic review.

Third, systematic review features apply the use of pre-determined criteria to assess the studies (Weed, 2005). This study's criteria were adapted from Martin's (2002) to understand the culture framework.

\section{Literature Review}

All recent researches in the literature reveal an explicit or implicit acceptance of the suggestion by Yukl et al. (2002) that effective leadership should correlate with subordinate behavior and culture. Various studies agreed that Leaders manage cultures and cultures are about people (e.g., Hofstede, 2000; Chhokar et al., 2007; House et al., 2004). Culture and Leadership are dependable on each other, as culture is considered as the operation system of leaders (Schein, 2006; Hui, Chiu, Yu, Cheng, and Tse, 2007). The contemporary model of organizational culture is categorized by the diversity of culture and demography (Yooyanyong \&

Table 1. Criteria for systematic review of literature.

\begin{tabular}{|c|c|c|c|}
\hline & \multicolumn{3}{|c|}{ Criteria } \\
\hline & Comprehensive review & Particular topic boundaries defined & $\begin{array}{c}\text { Pre-determined criteria } \\
\text { for evaluation of studies } \\
\text { and papers }\end{array}$ \\
\hline 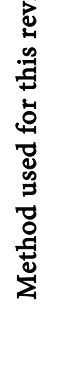 & $\begin{array}{l}\text { Search English language } \\
\text { journal's articles in } \\
\text { different databases such } \\
\text { as Scopus, Web of } \\
\text { Science, Google Scholar }\end{array}$ & $\begin{array}{l}\text { Egyptian Culture, Chinese Culture, } \\
\text { comparing Egyptian Culture with } \\
\text { other nation's culture, comparing } \\
\text { Chinese Culture with other nation's } \\
\text { culture. } \\
\text { - Only full-length peer-reviewed } \\
\text { articles } \\
\text { - Title, abstract or key words include } \\
\text { topics } \\
\text { - Period studies 2010-2019 }\end{array}$ & $\begin{array}{l}\text { Research interests } \\
\quad \text { Methods } \\
\text { Theories and Models } \\
\text { Research paradigm } \\
\text { Perspective of culture }\end{array}$ \\
\hline
\end{tabular}


Muenjohn, 2010; Chin and Sanchez-Hucles, 2007). Leaders need to create trust in the public and build harmony among followers and peers, same as inside and outside the group, firm and society (Kelley and Anderson, 2006).

National culture distinguishes one society from another society. Culture is viewed as the "underlying system of values peculiar to a specific group or society" (Pinillos and Reyes, 2011: p. 25). It is defined as "a set of shared values, beliefs and expected behaviors" (Hayton et al., 2002: p. 5); when we considered culture, theory applied on the level of institutional proposes that national culture encourages specific attitudes and behaviors coming from specific values and beliefs that describe each society as a unique (Hayton et al., 2002). Thus, entrepreneurial meaning and behaviors can be considered as an outcome of national culture effect (FakhrElDin et al., 2013). There is extensive and various agreement in the literature that there are differences in the entrepreneurial behavior between national cultures (FakhrElDin et al., 2013). Additionally, the values of cultural point to what extent the degree a society appreciates, encourages and cultivates certain behaviors depending on certain attitudes (Hayton et al., 2002; Fitzsimmons and Douglas, 2005). Additionally, perhaps each nation/country's culture will form a distinctive entrepreneurial culture related to its own history, values, norms, and beliefs (FakhrElDin et al., 2013; Russell, 1997). There are several frameworks and models applied in different studies and in the literature to analyze, style and identify culture, there are different dimensions in each model that focuses on specific variables (Hofstede, 1991, 1996; House et al., 2004; Inglehart and Welzel, 2005). "Most studies have hypothesized that entrepreneurship is facilitated by/in cultures that are high in individualism (i.e., low in collectivism), low in uncertainty avoidance, low in power distance and low in masculinity" [Hayton et al., 2002: p. 34; Fitzsimmons and Douglas, 2005: p. 5; FakhrElDin et al., 2013: p. 356]. Studies such as FakhrElDin et al. (2013) and Hayton et al. (2002) claimed that trust is considered as one of the variables which verified to have a crucial and fundamental effect on entrepreneurship, also, low power distance dimension of cultures is characterized by high level of trust that needs less monitoring and willingness to engage in entrepreneurial activities. Moreover, other scholars such as Chrisman et al. (2002) and FakhrElDin et al. (2013) analyzed the impact of national culture on entrepreneurial attitude, values, perceptions, performance and behavior, they concluded that families in society that have essential and important of influences on the formulation and development of business more than any other factor, mostly because they depend on the element of trust. Accordingly, there is a widespread acknowledgement of the fact that national culture, values and beliefs influence the entrepreneurial behaviors (FakhrElDin et al., 2013; Hayton et al., 2002; Thomas and Mueller, 2000; Russell, 1997).

To be able to understand how to link the leadership across culture, it is very important to understand the culture dimensions, but first we need to define culture. According to Dimmock and Walker (2000), culture is "the values, customs, traditions, and ways of living which distinguish one group of people from 
another" (p. 304). This definition is in line with Hofstede (1991) definition as "patterns of thinking, feeling, and acting underpinning the collective programming of the mind which distinguishes the members of one group or category of people from another" (p. 3). Hofstede's definition of culture mainly refers to the shared beliefs, values, practices of a collection of people which are called groups, these groups could be an organization; Society and/or nation state. Generally, the measurement cultures, Hofstede (1991) advocates the development of cultural dimensions as ways of describing, measuring and comparing cultures.

Dr. Geert Hofstede was a psychologist who developed his new famous framework while working at IBM. Hofstede (1984) gathered data from a large multinational corporation company, IBM. He collected data from forty different countries and analyzed it. Through his empirical study, he concluded that "organizations are cultural-bounded" (p. 252). Furthermore, he identified the four-dimension work-related culture which are power distance, uncertainty avoidance, individualism, and masculinity. These dimensions identified the cultural values dimensions in different countries as shown in "Table 2". The first dimension is power distance and it is most likely related to the inequality in power between managers and employees. In high power distance firms, organizational hierarchy is clear. A clear line between managers and employees in low power distance culture is applied to flat organizational structure.

As for the second dimension, uncertainty avoidance, it refers to people's acceptance of ambiguity as shown in "Table 2". Organizations that are characterized with high uncertainty avoidance have more written policy, rules and regulations in order to reduce uncertainty within the organization. While in low uncertainty avoidance organizations, there are fewer written rules and rituals.

Regarding the third dimension, individualism-collectivism, it refers to the perspective of people and how they value themselves and their groups/organiza-

Table 2. Six dimensions of the culture and management in Hofstede model.

Power Distance
The extent to which the less powerful members of society accept that
power is distributed unequally.
Collectivism: people belong to in-groups (families, organizations, etc.)
who look after them in exchange for loyalty. Individualism: people only
look after themselves and their immediate family.
Individualism
Masculinity: the dominant values in society are achievement and success.
Femininity: the dominant values in society are caring for others and
quality of life.
Uncertainty Avoidance

The 6 Cultural Dimensions of the Hofstede Model (Hofstede, Hofstede, \& Minkov, 2010). 
tions. An individual with high individualistic values is likely to care about self-actualization and career progress in the organization, while people with low individualistic values are likely to value organizational benefits more than their own benefits as shown in "Table 2".

Finally, the fourth dimension, masculinity defines and explains the gender roles in the organizations. In the high masculinity organizations, few women can obtain higher-level and better-paying posts as shown in "Table 2". While in low masculinity organizations, women can obtain status with equitable organizational.

In 1987, Chinese conducted a study based on traditional Chinese cultural values which they called the Chinese Value Survey (CVS). They identified this non-Western cultural dimension based on their survey which targeted students in 22 different universities. In this study, three of the four factors were correlated with the dimension of Hofstede's (1984) work-related culture. According to the Chinese study, the new four items of culture dimension included: ordering relationship, thrift, persistence and having a sense of shame. The new four items explained the Chinese society values. In 1990, Hofstede suggested the fifth dimension of culture called Long-Term Orientation (LTO) in his book Cultures and Organizations: Software of the Mind. This dimension was adopted according to Eastern cultural (work-related). In 2010, Hofstede added a sixth dimension: indulgence versus self-restraint.

\section{Indulgence vs. restraint:}

Indulgence is defined as "a society that allows relatively free gratification of basic and natural human desires related to enjoying life and having fun" (Hofstede, 2010: p. 8). This dimension as shown in "Table 2" is related to happiness measurement; is there any sign of joy fulfilled in the workplace. Similarly, Hofstede in 1991 defined indulgence as a society that controls gratification of needs and regulates it by means of strict social norms (Hofstede, 1991). The indulgent societies consider themselves able to control their own emotions, beliefs, and other societal factors.

Peters and Waterman (1982) claimed that Middle Eastern culture dimensions are considered to be strong and coherent more than western because Middle Eastern culture is infused with a system of values, beliefs, norms and ideals which are clearly well accepted, understood and adhered by all society members. These values and beliefs are controlled by wealthy mythology in the past history.

\section{GLOBE Model (Global Leadership and Organizational Behavior Effectiveness)}

The initial aim of the GLOBE (Global Leadership and Organizational Behavior Effectiveness) is a multi-phase and a multi-method to measure the culture and leadership characteristics across different cultures (House et al., 1999; Javidan and House, 2002; House et al., 2004). The project of GLOBE amusement tool is initiated by Robert House in 1993. The measurement framework tested the interrelationships and similarity between culture of societies and organizational 
Culture, relationships using these multiple methodologies. The measurement tested over 170 social scientists and management scholars from 62 countries in all major regions throughout the world have been engaged in the study of the relationship between culture and leadership (House et al., 1999; House et al., 2004). Egypt is one of these 62 countries which were involved in this study and has been included in the GLOBE research project. The GLOBE team reached an agreement on the definition of the two central concepts which are societal culture and leadership. House et al. (1999) defined leadership as "the ability of an individual to influence, motivate, and enable others to contribute towards the effectiveness and success of the organizations of which they are members" (p. 15). House et al. defined societal culture as "the commonality among members of collectives with respect to the psychological attributes ... and the commonality of observed and reported practices of entities such as families, schools, work organizations, economic and legal systems, and political institutions" (King and Zhang, 2014: p. 6).

These nine cultural dimensions mentioned above in "Table 1" have been identified as independent variables in different studies such as (House et al., 2004). The main nine dimensions as shown in "Table 1" are Uncertainty Avoidance, Power Distance, Institutional Collectivism, In-Group Collectivism, Gender Egalitarianism, Assertiveness, Future Orientation, Performance Orientation, and Humane Orientation. The cultural value dimensions are divided into two components: values and practices. First, the Value data that comes from answers to survey questions that ask, "What should be". Second, the Practice data that comes from answers to survey questions that ask, "what is (or are)", thus 18 scales to measure the practices and values with respect to the core GLOBE dimensions of culture (House et al, 2004).

GLOBE was designed to examine the acceptable and unacceptable existence of leadership attributes universally and to classify those traits that are specified based on culture perspective as shown in "Table 3". The theory depended on the implicit theory of leadership grounded. This theory argues that individuals have implicit theories about the traits and behaviors that differentiate moral leaders from immoral leaders and effective leaders from ineffective leaders (Elsaid and Elsaid, 2012 and House et al., 2004).

According to the study of GLOBE, Egypt is considered in the Middle Eastern cluster that also includes Turkey, Kuwait, Morocco, UAE and Qatar.

This study will use the researcher and studies conducted before for the systematic review, "Table 4" below shows the studies used in the systematic review.

\section{Comparison Based on the Previous Studies Discussion}

\subsection{Similarities and Differences}

Applying Hofstede's dimensions of culture to the Chinese and Egyptian culture as follows:

Small vs. Large Power Distance: The Chinese culture is characterized by an 
Table 3. Nine Dimensions of the culture measurement in GLOBE model.

\begin{tabular}{|c|c|}
\hline Power Distance & $\begin{array}{l}\text { Degree to which a culture's people are (should be) separated by power, } \\
\text { authority, and prestige }\end{array}$ \\
\hline In-Group Collectivism & $\begin{array}{l}\text { Degree to which a culture's people (should) take pride in and (should) } \\
\text { feel loyalty toward their families, organizations, and employers }\end{array}$ \\
\hline Institutional Collectivism & $\begin{array}{l}\text { Degree to which individuals are (should be) encouraged by institutions } \\
\text { to be integrated into broader entities with harmony and cooperation as } \\
\text { paramount principles at the expense of autonomy and individual } \\
\text { freedom }\end{array}$ \\
\hline Uncertainty Avoidance & $\begin{array}{l}\text { Degree to which a culture's people (should) seek orderliness, } \\
\text { consistency, and structure }\end{array}$ \\
\hline Future Orientation & $\begin{array}{l}\text { Degree to which a culture's people are (should be) willing to defer } \\
\text { immediate gratification for future benefits }\end{array}$ \\
\hline Gender Egalitarianism & Degree to which a culture's people (should) support gender equality \\
\hline Assertiveness & $\begin{array}{l}\text { Assertiveness Degree to which a culture's people are (should be) } \\
\text { assertive, confrontational }\end{array}$ \\
\hline Humane Orientation & $\begin{array}{l}\text { Degree to which a culture's people are (should be) fair, altruistic, } \\
\text { generous, caring, and kind toward others }\end{array}$ \\
\hline Performance Orientation & $\begin{array}{l}\text { Degree to which a culture's people (should) encourage and reward } \\
\text { people for performance }\end{array}$ \\
\hline
\end{tabular}

The descriptions are derived from: House, Hanges, Javidan, Dorfman, \& Gupta (2004). Culture, Leadership, and Organizations. The GLOBE Study of 62 Societies. Thousand Oaks, CA: Sage.

Table 4. List of publications used in this study.

\begin{tabular}{|c|c|c|}
\hline & Egypt/MENA region's publications & China's publications \\
\hline 1 & $\begin{array}{l}\text { Elsaid (2012) "Culture and Leadership: } \\
\text { Comparing Egypt to the GLOBE Study of } \\
\text { Societies", Business and Management } \\
\text { Research, Vol. 1, No. 2, pp. 1-13. }\end{array}$ & $\begin{array}{l}\text { Shi and Wang (2011) Culture Distance between } \\
\text { China and US across GLOBE Model and } \\
\text { Hofstede Model, International Business and } \\
\text { Management, Vol. 2, No.1. 2011, pp. 11-17. }\end{array}$ \\
\hline 2 & $\begin{array}{l}\text { Kirby \& Ibrahim (2011). } \\
\text { Entrepreneurship education and the creation } \\
\text { of an enterprise culture: Provisional results } \\
\text { from an experiment in Egypt. International } \\
\text { Entrepreneurship and Management Journal. } 7 . \\
\text { 181-193. 10.1007/s11365-010-0153-0. }\end{array}$ & $\begin{array}{l}\text { Bluszcz and Quan (2016) Cultural Comparison } \\
\text { between China and Germany Based on Hofstede } \\
\text { and Globe", International Journal of Marketing, } \\
\text { financial services \& Management Research, Vol. } \\
5 \text { (10), October (2016), pp. 58-68. }\end{array}$ \\
\hline 3 & $\begin{array}{l}\text { FakhrEldin (2011), The Effect of Cultural } \\
\text { Intelligence on Employee Performance in } \\
\text { International Hospitality Industries: A Case } \\
\text { from the Hotel Industry in Egypt, The } \\
\text { International Journal of Business and Public } \\
\text { Administration, Vol. 8, pp. 1-19. }\end{array}$ & $\begin{array}{l}\text { King and Zhang (2014) Chinese and Western } \\
\text { Leadership Models: a Literature review, Journal } \\
\text { of Management Research, Vol. 6, No. } 2 \text {. }\end{array}$ \\
\hline 4 & $\begin{array}{l}\text { FakhrElDin, Skoko, \& Cheraghi (2013), The } \\
\text { effect of national culture on } \\
\text { entrepreneurs' networks: A comparison of the } \\
\text { MENA region and Denmark, International } \\
\text { Journal of Business and Globalization, } 11 \text { (4), } \\
\text { pp. 353-366. }\end{array}$ & $\begin{array}{l}\text { Hofstede \& Hofstede (2016). Dimension Data } \\
\text { Matrix. Retrieved from } \\
\text { personal Homepage of Geert \& Gert Jan } \\
\text { Hofstede. }\end{array}$ \\
\hline
\end{tabular}




\section{Continued}

Fakhreldin \& Elghetany (2016), The

Relationship between Organizational Culture

and Job Satisfaction: An International

5 Perspective. Proceedings of the 4 th

5 International Conference on Management, Leadership and Governance (ICMLG), Saint Petersburg University of Economics, St. Petersburg, Russia, April 14-15, 2016.

Adisu, Sharkey, and Okoroafo, (2010) The Impact of Chinese investment in Africa, Internation6 al Journal of Business and management, Vol. 5, No.9.

Shi and Wang (2011) Interpreting Hofstede Model and GLOBE Model: Which Way to Go for Cross-Cultural Research? International Journal of Business and Management. Vol. 6, No. 5.

Zhang (2013) Cultural Conflicts and Counterstrategies between Russia and China in

8 Cross-cultural Communication, Department of Social Sciences, Shandong, Jiaotong University, Jinan, China.

authoritarian attitude as well as a cultural gap between the lower and upper classes as well. The Chinese business environment is restricted with these divisions of power positions; therefore, China and Egypt are countries with large power distance as shown in "Figure 1". For both societies, their hierarchical nature means that these aspects pervade the business world as well and it is common for the employees at the lower levels to adopt hierarchical communication with their superiors.

Individualism vs. Collectivism: According to Hofstede's dimension of individualism versus collectivism, Egypt would be categorized as a collectivist society, same as China as shown in "Figure 1". China tends to favor the group above the individual and the groupthink or the group behavior that Chinese are encouraged to adopt. This means that this dimension can be characterized as low individualism. In a collectivist society, leaders tend to work in groups and have a higher ordinal goal that they work to achieve it as same as Egypt and China. With these values and within an organizational context, membership in or affiliation with groups such as prominent families and influential social circles can provide employment opportunities, as well as influencing the treatment an individual can receive within the organization (Herrera et al., 2011; Minkov \& Hofstede, 2014; Mirabela and Madela, 2013). Low levels of individualism suggest a tendency for success in the workplace to be more daunting for those who do not adhere to a more collectivist mentality.

Masculinity vs. Femininity: according to Hofstede's dimension of masculinity versus femininity, Egypt is categorized as a masculine society, whereas in the Chinese culture, masculine and feminine societies are equally regarded. This means that gender stereotypes and biases are absent in China. Hence, China scores favorably with the West in this dimension. Index suggests that the Egyptian society is largely masculine in nature. For society, and the workplace, the greatest implication of this score is that life is often seen as vehicle for work more than enjoyment (Herrera et al., 2011; Minkov \& Hofstede, 2014; Mirabela and Madela, 2013). 


\section{China and Egypt' culture according to Hofstede's dimensions}

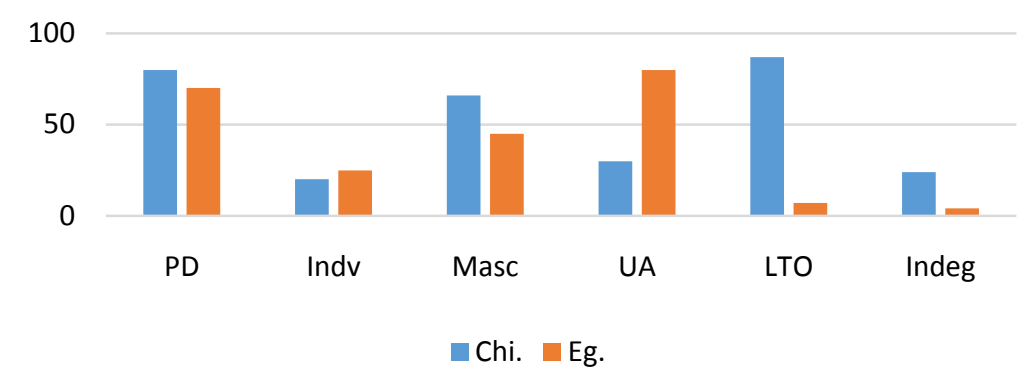

Figure 1. China and Egypt's culture according to Hofstede's dimensions.

Weak vs. Strong Uncertainty Avoidance: As with the previous dimension, the ranking for this aspect of the framework for China is deceiving. This dimension refers to people's acceptance of ambiguity. Organizations that are distinguished with a high uncertainty avoidance have more written policies rules and regulations in order to reduce uncertainty within the organization. While in low uncertainty avoidance organizations, there are fewer written rules and rituals. As with the previous dimension, the ranking for this aspect of the framework for China is deceiving. Countries with low uncertainty avoidance tend to be those where people are relatively free and hence tolerate uncertainty and ambiguity at the workplace. Further, a low score indicates that people are not controlled to a large extent. However, this is not the case with China (despite the economy opening up) where people are controlled to a large extent. This is because of the strong cultural acceptance of conformity and hence though one might not be thrown in jail for breaking a law, the cultural aspect of "losing face" means that people tend to obey the laws and rules. At the workplace, this manifests itself in terms of employees needing strong guidance rather than taking decisions on the spot. Egypt as a nation received scores of 70 for power distance, 25 for individualism, 45 for masculinity, 80 for uncertainty avoidance, 7 for long-term orientation (pragmatism) (Minkov \& Hofstede, 2014). Index reveals that members of the Egyptian society prefer to avoid the majority of uncertain situations; prefer to let the future take its course and adapt alongside it as it unfolds. Within the context of organizational life, cultures exhibiting similar traits tend to adhere to very rigid codes of conduct and a small range of acceptable behavior, with a low tolerance for ideas and behaviors that deviate from established norms (Herrera et al., 2011; Minkov \& Hofstede, 2014; Mirabela \& Madela, 2013). High levels of uncertainty avoidance suggest that the Egyptian society is characterized by very conservative decision making and a high aversion to risk-taking.

Long vs. Short Term Orientation: The Chinese characteristically have a longer-term orientation that means they would think longer-term rather than a short-term basis. Since the country aspires to be the next superpower, there is definitely a tendency to think big and think ahead. Further, the nature of doing business in China is such that things take a longer time to complete, which the 
same natural like Egyptian. In other words, for this dimension, the Chinese culture and business can be said to be influenced with a longer-term perspective that is similar to the Egyptian procedures, which will show that there will be an understanding between the two countries in the business environment and such a harmony will take place between both societies. The Chinese Culture is strongly infused with a historical sense of greatness and hence it is common for the Chinese to have a perspective of time that is highly regarded compared to the West. This accounts for the longer-term perspective that the Chinese have. They tend not to worry themselves with future circumstances as much as they preserve the past and the present. In terms of organizational life, this means that preservation of current status quos and respect for traditional methods are highly appreciated (Minkov \& Hofstede, 2014).

Indulgence vs. Restraint or Aggressiveness: In this dimension, the Chinese can be on the restraint or the less aggressive edge as the culture does not encourage overt displays of aggression. Moreover, the Chinese do not exhibit the typical gender gap or the difference between men and women to the extent which Egyptians tend to display. However, the Chinese society is not as open as the Egyptian one. As a result, in this dimension, China tends to score the middle of the road measure while Egypt scored less than 10. As shown in "Figure 1".

In conclusion, the Chinese tend to encourage strict management and high organizational performance. So, it is somewhat of a balancing act for the Chinese as far as this dimension is concerned. Egypt highly favors restraint overindulgence through legal and social regulations as shown in "Figure 1". The Egyptian society therefore places a great deal of importance on modesty, religious practices and repression. A society that favors restraint likely sees the manifestation of this trait in intra-organizational relations more than any particular performance metric, but the importance of intra-organizational relations to the contemporary business environment means there are likely many implications of this finding (Wilderom et al., 2012; Minkov \& Hofstede, 2014). While this score might have its greatest implications for the way members conduct their personal lives, within an organizational context, this cultural dimension still has meaning.

By looking at "Figure 2" (a and b) and "Table 5", and according to the result above, the score of GLOBE data for Egypt sample is fairly high for power distance and in group collectivism (IGC). Egypt is scored in group collectivism in the scale 6.03 (Elsaid, 2012). A prominent feature of the Egyptian societal culture is the extent to which Egyptians show Loyalty, express pride and cohesiveness towards family, organization and other in-group collectivities compared with China that scores significant high in both practices (5.86) and higher in Value (5.12) (Shi and Wang, 2011). In assertiveness (AO) Egypt's mean score was 4.04 while China scored 3.77 in practices and in value scored 5.52 (Elsaid, 2012 and Shi and Wang, 2011). In Power Distance (PD) Egypt's scored 5.43 compared while China scored in Practices (5.02) and Value scored (3.01). In Future orientation (FO), Egypt scored 3.7, while China scored 3.68 in practice and 4.7 in 
Table 5. China and Egypt GLOBE cultural dimensions according to different studies as mentioned in Figure 2 above.

\begin{tabular}{ccccccccccccccccccc}
\hline \multicolumn{1}{c}{ AO } & & IC & & IGC & & FO & & GE & & HO & & PO & & PD & & \multicolumn{2}{c}{ UA } \\
\hline P & V & P & V & P & V & P & V & P & V & P & V & P & V & P & V & P & V \\
\hline
\end{tabular}

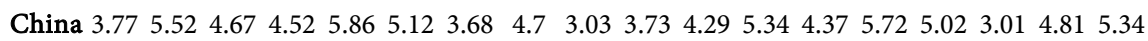

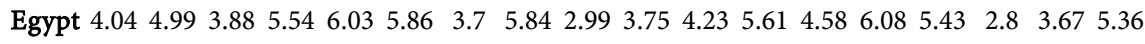

Notes: 1) $\mathrm{AO}=$ Assertiveness Orientation, IC = Institutional Collectivism, IGC = In-Group Collectivism, $\mathrm{FO}=$ Future, Orientation, $\mathrm{GE}=$ Gender Egalitarianism, $\mathrm{HO}=$ Humane Orientation, $\mathrm{PO}=$ Performance Orientation, $\mathrm{PD}=$ Power Distance, $\mathrm{UA}=$ Uncertainty Avoidance, $\mathrm{P}=$ Practice, $\mathrm{V}=$ Value. 2) Data derived from House, Hanges, Javidan, Dorfman, \& Gupta (2004). Culture, Leadership, and Organizations. The GLOBE Study of 62 Societies. Thousand Oaks, CA: Sag.

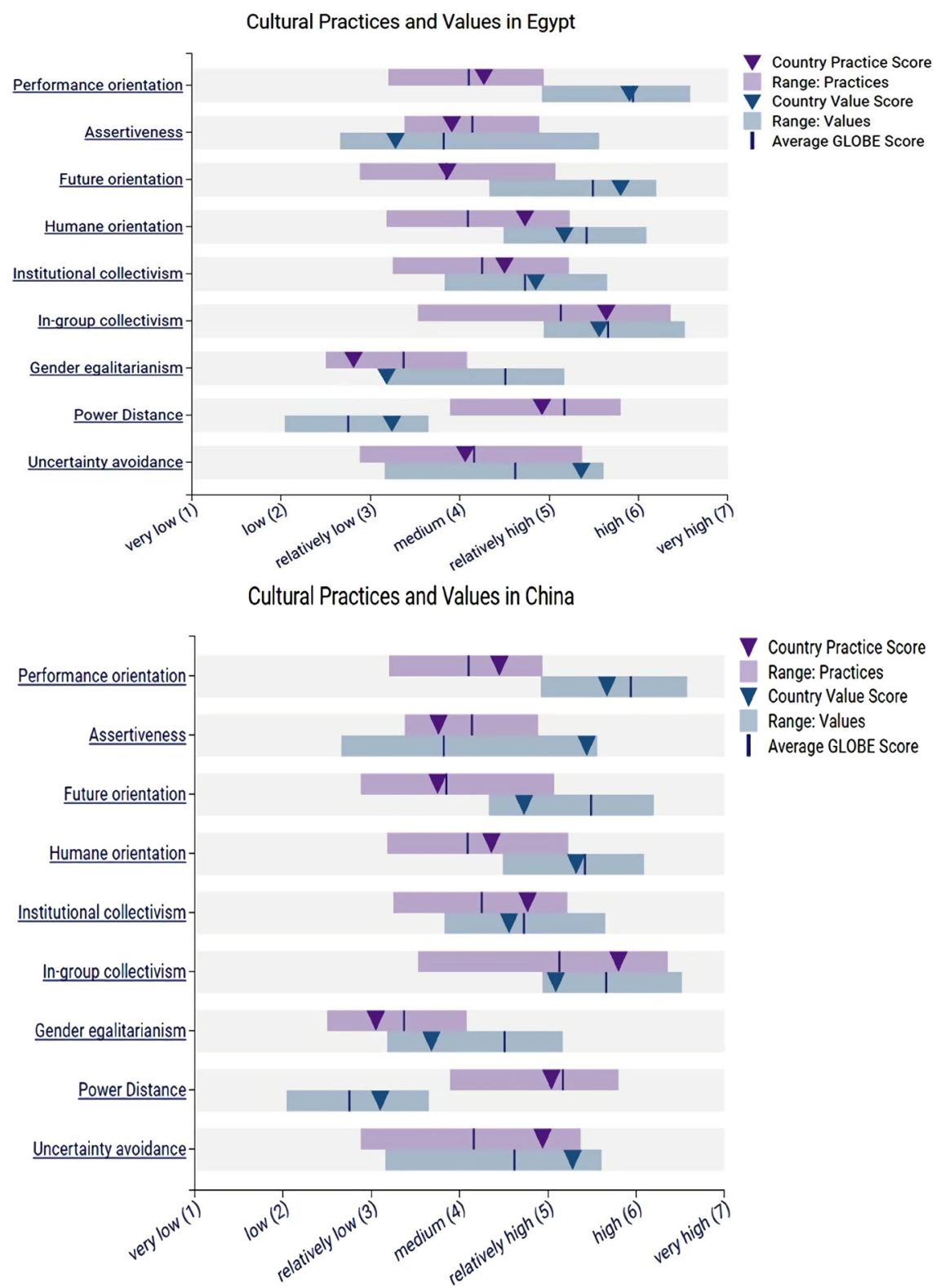

Figure 2. Cultural distance between China and US across GLOBE model and Hofstede model. The table retrieve from the GLOBE 2020 (Global Leadership and organisational Behaviour Effectiveness) in Feb. 2020. 
value, both of them are considered as Lower scored in most of the studies. In Gender Egalitarianism (GE), Egypt scored 2.99 while China scored 3.03 in practice and 3.73 in value. China is considered higher than Egypt but considered significantly lower compared to other countries like US. In the dimension of Uncertainty Avoidance (UA), Egypt scored 3.67 while China scored 4.81 in practice and 5.34 in value. In Human orientation (HO), Egypt scored 4.23 while China scored in practice 4.29 and in value 5.34. In Performance Orientation (PO), Egypt scored 4.58 while China scored 4.37 in practice and 5.72 in value. In institutional Collectivism (IC) or Social Collectivism (SC), Egypt scored 3.88 while China scored 4.67 in practice and 4.52 in value.

\subsection{Theoretical Implication}

Using Hofstede and GLOBE Models are highly valuable in business and management research. Both Models provide valuable dimensions for making an effective comparison between Egypt and China and give a clear understanding of the similarities and the differences between different countries' culture. Although there is a debate about the appropriateness and the validity of these Models (Posthuma \& Campion, 2009), there is a contrast between both Models in scores related to China and Egypt.

When this study examined social cultural dimension applying the nine GLOBE Model dimensions from the perspective of other studies, Egypt scores appeared low in assertiveness, social collectivism, uncertainty avoidance, gender egalitarianism and future orientation. Nevertheless, Egypt scored high in-group collectivism, performance orientation, human orientation and power distance (Elsaid, 2012).

On the level of theoretical implication, it is highly recommended to do further future research and investigation of Hofstede and GLOBE Models as well as on cross-cultural communication, investigation, leadership and management approach.

On the practical level, mangers seek more cooperation with the Chinese companies; they should equip and raise awareness of their companies with the history of the Chinese Culture. In addition, before starting cooperation, company managers have to consider the cross-cultural elements in raising awareness of each other's culture and national culture as well.

\section{The Impact of COVID-19 on Belt and Road Initiative (BRI)}

The world has been hit by an unprecedented health crisis that rapidly spread in many countries. This rapid outbreak of COVID-19 could be justified and interpreted as a result of the globalization that creates a high level of interconnection and interdependence between countries. It could be considered as the downside and negative aspect of globalization.

When the WHO declared COVID-19 a "global pandemic", borders have been closed, many industries and workers were asked to stop their work and to stay 
home. Accordingly, the initiative has become no longer at the top of the Chinese's priorities. Beijing is seeking to mitigate the effects of the pandemic on the internal economic, political and social status. This does not mean that China will abandon the project, but there will be a temporary delay in resuming the work on the current projects.

The current situation will force the Chinese government to alter its plans to focus more, especially on the short term, on both the "Health Silk Road" and the emphasis on the "Digital Silk Road". The great importance of these two strategies has been witnessed during the pandemic.

\subsection{The "Health Silk Road"}

The Health Silk Road is not a new concept; it is a part of the BRI since its adoption in 2013. In early 2015, the Chinese government realized the necessity of increasing its "voice and influence in multilateral health governance through health cooperation in BRI countries" (Pal and Bhatia, 2020: p. 1). Later in 2017, China and WHO signed a memorandum of understanding where they announced the launching of the Health Silk Road as an ambitious project to improve and develop the health public system in all the country and especially the state parties in the BRI. It was planned for the health initiative to provide a common platform in order to enhance the capabilities of the states' partners to BRI to deal with the epidemic emergencies by sharing best practices and information in addition to provide medical aids. The question is to what extent the stated objectives have been realized. Since this time, "China has become more proactive in global health governance" (Chan, Chen, and Xu, 2010: p. 4). China increased its investment in the Global health sector to ensure an international advanced position among the other countries.

The strategy of Soft power adopted by Beijing to become the global health leader has apparently reached its objectives during the outbreak of the pandemic through the "Soft Medical Diplomacy" implemented in many countries especially in some European countries, mainly in Italy and Serbia. As a result of this aid, Italy has become the first European country participating in the BRI Road by signing a Memorandum of Understanding (MoU) with China.

This crisis demonstrated the fragility of the health infrastructure in the majority of countries. The Health Silk Care is now on the top priorities of Beijing and it will certainly remain in the near future in order to guarantee its superiority especially if China succeeds in reaching a treatment or a vaccine to COVID-19. China proceeded during the last months to achieve the objectives of Health Silk Road through tangible steps, especially by providing medical aids. China has sent medical experts and medical assistance to many countries around the world to help them in the fight of COVID-19. This assistance, directly assured by Chinese embassies and companies, is known as the "Mask Diplomacy".

One of the main projects that China should focus on is the reinforcement and improvement of the public health systems in the BRI countries in order to have 
future plans and precautions in case of any further pandemic or disease crisis.

\subsection{The "Digital Silk Road"}

The technology plays an important role in the Chinese economy as the government seeks to be the leader in the Digital market to lead the global digitalization. The ambitious "Digital Silk Road" has been launched alongside the Belt and Road Initiative and has been integrated into the projects of infrastructure which will have many benefits for the participating countries such as guarantee the speed transfer of information between the countries. This could enhance a positive influence that

"deemed to minimize cultural differences, reduce asymmetric information, build trust for Belt and Road countries and regions, and stimulate cooperation in multiple fields such as information infrastructure, trade, finance, industries, science, education, culture, and health" (Ajey and Roy, 2019: p. 19).

Technology and digital activities have been widely used during the pandemic period by China to fight the virus and to mitigate the economic impacts of the closure of commerce and business. The successful model of China has encouraged other countries, particularly BRI partners to do the same and to depend on technology and artificial intelligence to contain the virus and to survive this hard period.

The severity of the shutting down of the Chinese economy for almost three months has been moderated by the rise of digital economy which gave China the opportunity to open new markets. This business model has positioned China as the global leader of digital market.

\section{Conclusion}

There is a high attention towards China and Africa collaboration and investments as China has provided around $\$ 60$ billion financial support to Africa which will definitely strengthen the Belt and Road Initiative (BRI). The study identifies three main results by examining, both Hofstede and GLOBE Models which can enhance the strategic cooperation between both countries. In LTO, China scored higher than Egypt, however, both China and Egypt were scored closer to collectivism. As for PDI, China has scored higher than Egypt but it is not significant as the difference is only 10 . With reference to the GLOBE Model, the differences in PDI and IDV dimensions are not as great as in Hofstede Model.

As for the future research, this study recommends further future research and investigation of these two applications of the Hofstede and GLOBE Models, and further research on cross-culture communication, investigation, leadership and management approach. Focuses on the more influencing dimensions in the Models have a big impact on the relationship in cross culture theme.

Regarding the strategic cooperation on Belt and Road Initiative, it is clear that 
the situation after the outbreak of COVID-19 pandemic will force China to prioritize its national interests by redirecting its financial resources to be allocated on the short term to stabilize the internal situation and to recover the Chinese economy. The pace of implementation of BRI projects and activities will be adapted according to the current situation. This also will definitely delay the Chinese construction and investment plans previously set out before the pandemic. Accordingly, China has to reform the BRI initiative by adopting corrective measures and reforming the policies in order to consider the consequences of this pandemic and mitigate its negative impacts. The use of technology will be accelerated, and the role of private sector should be more significant. China has proved that it has been able to change the image from being the source of COVID-19 pandemic and to benefit from the crisis by making itself the big brother and the savior of other countries, especially after the defeatist attitude of the United States of America. Moreover, China seeks to enhance its international standing and to achieve economic gains.

Finally, it is important to say that the real impact of COVID-19 on the BRI is still unclear. However, it is not conceivable that the Chinese government will abandon the initiative. A big part of the project, initiated as an idea in 2013, has been invested and this should continue. The current situation could motivate the Chinese government to modify its attitude and its perception to adopt a clear and comprehensive strategy of the BRI by including more partners, cooperating with the private sector, and relying on various secured financial methods.

\section{Conflicts of Interest}

The authors declare no conflicts of interest regarding the publication of this paper.

\section{References}

Adisu, K., Sharkey, T., \& Okoroafo, S. (2010). The Impact of Chinese Investment in Africa. International Journal of Business and Management, 5, 3. https://doi.org/10.5539/ijbm.v5n9p3

Ajey, L., \& and Roy, K. (2019). Analysing China's Digital and Space Belt and Road Initiative. Institute for Defence Studies and Analyses, New Delhi, IDSA Occasional Paper No. 54.

Alvesson, M. (2002). Understanding Organizational Culture. London: Sage. https://doi.org/10.4135/9781446280072

Bass, B. M. (1985). Leadership and Performance beyond Expectations. New York: Free Press.

Bass, B. M., \& Avolio, B. J. (1993). Transformational Leadership and Organizational Culture. Public Administration Quarterly, 17, 112-121.

Bluszcz, M., \& Quan, S. H. A. (2016). Cultural Comparison between China and Germany Based on Hofstede and Globe. International Journal of Marketing, Financial Services \& Management Research, 5, 58-68.

Chan, L. H., Chen, L., \& Xu, J. (2010). China's Engagement with Global Health Diplomacy: Was SARS a Watershed? PLOS Medicine, 7, e1000266. 
https://doi.org/10.1371/journal.pmed.1000266

Chhokar, J. S., Brodbeck, F. C., \& House, R. J. (2007). Culture and Leadership across the World: The GLOBE Book of in-Depth Studies of 25 Societies. Mahweh, NJ: LEA Publishers.

Chin, J. L., \& Sanchez-Hucles, J. (2007). Diversity and Leadership. American Psychologist, 62, 608-609. https://doi.org/10.1037/0003-066X62.6.608

Chrisman, J., Chua, J., \& Steier, L. (2002). The Influence of National Culture and Family Involvement on Entrepreneurial Perceptions and Performance at the State Level. Entrepreneurship Theory and Practice, 26, 113-130.

https://doi.org/10.1177/104225870202600407

Culver, D. M., Gilbert, W. D., \& Sparkes, A. (2012). Qualitative Research in Sport Psychology Journals: The Next Decade 2000-2009 and beyond. The Sport Psychologist, 26, 261-281. https://doi.org/10.1123/tsp.26.2.261

Dimmock, C., \& Walker, A. (2000). Globalizations and Societal Culture: Redefining Schooling and School Leadership in the Twenty-First Century. London: Falmer Press. https://doi.org/10.1080/713657474

Elsaid, A., \& Elsaid, E. (2012). Sex Stereotyping Managerial Positions: A Cross-Cultural Comparison between Egypt and the USA. Gender in Management: An International Journal, 27, 81-99. https://doi.org/10.1108/17542411211214149

Elsaid, E. (2012). Culture and Leadership: Comparing Egypt to the Globe Study of Societies. Business and Management Research, 1, 1-13.

FakhrEldin, H. (2011). The Effect of Cultural Intelligence on Employee Performance in International Hospitality Industries: A Case from the Hotel Industry in Egypt. The International Journal of Business and Public Administration, 8, 1-19.

Fakhreldin, H., \& Elghetany, H. (2016). The Relationship between Organizational Culture and Job Satisfaction: An International Perspective. In Proceedings of the 4th International Conference on Management, Leadership and Governance (p. 32). Leicester: Leicester University.

FakhrElDin, H., Skoko, H., \& Cheraghi, M. (2013). The Effect of National Culture on Entrepreneurs' Networks: A Comparison of the MENA Region and Denmark. International Journal of Business and Globalization, 11, 353-366. https://doi.org/10.1504/IJBG.2013.056873

Fitzsimmons, J., \& Douglas, E. (2005). Entrepreneurial Attitudes and Entrepreneurial Intentions: A Cross-Cultural Study of Potential Entrepreneurs in India, China, Thailand and Australia. In Babson-Kauffman Entrepreneurial Research Conference (pp. 1-19). Wellesley: Brisbane Graduate School of Business.

Girginov, V. (2010). Culture and the Study of Sport Management. European Sport Management Quarterly, 10, 397-417. https://doi.org/10.1080/16184742.2010.502741

Hayton, J. C., George, G., \& Zahra, S. A. (2002). National Culture and Entrepreneurship: A Review of Behavioral Research. Entrepreneurship Theory and Practice, 26, 33-52. https://ink.library.smu.edu.sg/lkcsb_research/4642 https://doi.org/10.1177/104225870202600403

Herrera, R., Duncan, P. A., Green, M., Ree, M., \& Skaggs, S. L. (2011). The Relationship between Attitudes toward Diversity Management in the Southwest USA and the GLOBE Study Cultural Preferences. International Journal of Human Resource Management, 22, 2629-2646. https://doi.org/10.1080/09585192.2011.588037

Hofstede, G. (1984). Culture's Consequences: Institutional Differences in Work-Related Values. Abridged Edition, Beverly Hills, CA: Sage. 
Hofstede, G. (1991). Cultures and Organizations: Software of the Mind. Maidenhead: McGraw Hill.

Hofstede, G. (1996). Riding the Waves of Commerce: A Test of Tromenaars' "Model” of National Cultural Differences. International Journal of Intercultural Relations, 20, 189-197. https://doi.org/10.1016/0147-1767(96)00003-X

Hofstede, G. (2000). Culture's Consequences: Comparing Values, Behaviors, Institutions and Organizations across Nations. Thousand Oaks, Calif.: Sage Publications.

Hofstede, G. (2001). Culture's Consequences (2nd ed.). Thousand Oaks, CA: Sage.

Hofstede, G. (2010). The Globe Debate: Back to Relevance. Journal of International Business Studies, 41, 1339-1346. https://doi.org/10.1057/jibs.2010.31

Hofstede, G. (2011). Dimensionalizing Cultures: The Hofstede Model in Context. Online Readings in Psychology and Culture, 2, Article 8.

https://doi.org/10.9707/2307-0919.1014

Hofstede, G. H., Hofstede, G. J., \& Minkow, M. (2010). Cultures and Organizations: Software of the Mind (3rd ed.). New York, NY: McGraw-Hill.

Hofstede, G., \& Hofstede, G. J. (2016). Dimension Data Matrix. Retrieved from Personal Homepage of Geert \& Gert Jan Hofstede.

Holt, S., Bjorklund, R., \& Green, V. (2009). Leadership and Culture: Examining the Relationship between Cultural Background and Leadership Perceptions. The Journal of Global Business Issues, 3, 149-164.

House, R. J., Hanges, P. J., Javidan, M., Dorfman, P., \& Gupta, V. (2004). Culture, Leadership, and Organizations: The Globe Study of 62 Societies. Thousand Oaks, CA: Sage Publications.

House, R., Hanges, P., Ruiz-Quintanilla, S., Dorfman, P., Javidan, M., Dickson, M., \& Gupta, V. (1999). Cultural Influences on Leadership and Organizations: Project Globe. Advances in Global Leadership, 1, 171-233.

Hui, C. H., Chiu, W. C., Yu, P. L., Cheng, K., \& Tse, H. (2007). The Effects of Service Climate and the Effective Leadership Behavior of Supervisors on Frontline Employee Service Quality: A Multi-Level Analysis. Journal of Occupational and Organizational Psychology, 80, 151-172. https://doi.org/10.1348/096317905X89391

Inglehart, R., \& Welzel, C. (2005). Modernization, Cultural Change and Democracy. New York: Cambridge University Press.

Javidan, M., \& House, R. J. (2002). Leadership and Cultures around the World: Findings from GLOBE: An Introduction to the Special Issue. Journal of World Business, 37, 1-2. https://doi.org/10.1016/S1090-9516(01)00068-2

Kelley, C. L., \& Anderson, S. (2006). Advising Nonprofit Organizations. The CPA Journal, 76, 20-26.

King, P., \& Zhang, W. (2014). Chinese and Western Leadership Models: A Literature Review. Journal of Management Research, 6, 1-21. https://doi.org/10.5296/jmr.v6i2.4927

Kirby, D., \& Ibrahim, N. (2011). Entrepreneurship Education and the Creation of an Enterprise Culture: Provisional Results from an Experiment in Egypt. International Entrepreneurship and Management Journal, 7, 181-193. https://doi.org/10.1007/s11365-010-0153-0

Klassen, T. P., Jahad, A. R., \& Moher, D. (1998). Guides for Reading and Interpreting Systematic Reviews. Archives of Pediatric \& Adolescent Medicine, 152, 700-704. https://doi.org/10.1001/archpedi.152.7.700

Managa, L. R., \& Simelane, T. (2018). Belt and Road Initiative: Alternative Development 
Path for Africa. Arcadia: Africa Institute of South Africa.

Martin, J. (2002). Organizational Culture: Mapping the Terrain. London: Sage. https://doi.org/10.4135/9781483328478

Miller, V. L. (2004). An Examination of Contemporary Marketing Prospects Used by Organizations.

Minkov, M. (2012). What Do Project GLOBE’s Cultural Dimensions Reflect? An Empirical Perspective. Asia Pacific Business Review, 18, 27-43. https://doi.org/10.1080/13602381.2010.496292

Minkov, M., \& Hofstede, G. (2014). A Replication of Hofstede's Uncertainty Avoidance Dimension across Nationally Representative Samples from Europe. International Journal of Cross Cultural Management, 14, 161-171. https://doi.org/10.1177/1470595814521600

Mirabela, M., \& Madela, A. (2013). Cultural Dimensions and Work Motivation in the European Union. Annals of the University of Oradea, Economic Science Series, 22, 1511-1519. http://anale.steconomiceuoradea.ro/

Morgan, G. (1997). Images of Organization. Thousand Oaks, CA: SAGE.

Nafie, R., \& Jones, S (2012). Knowledge Is Power; Knowledge Management Petitive Advantage: An Example from Egypt. In N Delener (Ed.), Service Science Research, Strategy and Innovation: Dynamic Knowledge Management Methods (pp. 574-604). Hershey, PA: IGI Glob. https://doi.org/10.4018/978-1-4666-0077-5.ch031

Pal, D., \& Bhatia, R. (2020). The BRI in Post-Coronavirus South Asia. Washington DC: Carnegie Endowment for International Peace.

Peters, T., \& Waterman, R. (1982). In Search of Excellence: Lessons from America's Best Run Companies. New York: Harper \& Row.

Pinillos, M. J., \& Reyes, L. (2011). Relationship between Individualist-Collectivist Culture and Entrepreneurial Activity: Evidence from Global Entrepreneurship Monitor Data. Small Business Economics, 37, 23-37. https://doi.org/10.1007/s11187-009-9230-6

Posthuma, R. A., \& Campion, M. A. (2009). Age Stereotypes in the Workplace: Common Stereotypes, Moderators, and Future Research Directions. Journal of Management, 35, 158-188. https://doi.org/10.1177/0149206308318617

Russell, R. D. (1997). The Impact of National Culture on the Emergence of Entrepreneurship. In Proceedings of the 42nd World Conference Entrepreneurship: The Engine of Global Economic Development, International Council for Small Business. Prague: ICSB.

Schachter, E. P. (2005). Erikson Meets the Postmodern: Can Classic Identity Theory Rise to the Challenge? Identity, 5, 137-160. https://doi.org/10.1207/s1532706xid0502_4

Schein, E. H. (1992). Organizational Culture and Leadership (2nd ed.). San Francisco, CA: Jossey-Bass.

Schein, E. H. (2006). Organizational Culture and Leadership. San Francisco, CA: Jossey-Bass.

Shi, X. M., \& Wang, J. Y. (2011). Cultural Distance between China and US across GLOBE Model and Hofstede Model. International Business and Management, 2, 11-17.

Thomas, A., \& Mueller, S. (2000). A Case for Comparative Entrepreneurship: Assessing the Relevance of Culture. Journal of International Business Studies, 31, 267-301. https://doi.org/10.1057/palgrave.jibs.8490906

Weed, M. (2005). Meta Interpretation: A Method for the Interpretive Synthesis of Qualitative Research. FQS, 6, Article No. 37. 
Wilderom, C. P. M., van den Berg, P. T., \& Wiersma, U. J. (2012). A Longitudinal Study of the Effects of Charismatic Leadership and Organizational Culture on Objective and Perceived Corporate Performance. The Leadership Quarterly, 23, 835-848.

https://doi.org/10.1016/j.leaqua.2012.04.002

Yooyanyong, P., \& Muenjohn, N. (2010). Leadership Styles of Expatriate Managers: A Comparison between American and Japanese Expatriates. The Journal of American Academy of Business, Cambridge, 15, 161-167.

Yukl, G., Gordon, A., \& Taber, T. (2002). A Hierarchical Taxonomy of Leadership Behavior: Integrating a Half Century of Behavior Research. Journal of Leadership and Organizational Studies, 9, 15-32. https://doi.org/10.1177/107179190200900102

Zhang, Y. X. (2013). Cultural Conflicts and Counterstrategies between Russia and China in Cross-Cultural Communication. Jinan: Department of Social Sciences, Shandong Jiaotong University. 